\title{
STUDI LAPANG: PENEGAKAN DIAGNOSIS INFECTIOUS BURSAL DISEASE (IBD) PADA AYAM BROILER
}

\author{
The Field Study: Enforcement of Diagnosis Infectious Bursal Disease (IBD) \\ in Broiler Chickens
}

\author{
Aan Awaludin', Yudhi Ratna Nugraheni' ${ }^{2}$, Theo Mahiseta Syahniar', Dyah Laksito \\ Rukmi ${ }^{1}$, Agus Hadi Prayitno ${ }^{1}$, dan Nurkholis ${ }^{1}$ \\ ${ }^{1}$ Jurusan Peternakan, Politeknik Negeri Jember \\ ${ }^{2}$ Fakultas Kedokteran Hewan, Universitas Gadjah Mada \\ Email: aanawaludin@polije.ac.id
}

\begin{abstract}
INTISARI
Infectious Bursal Disease (IBD) atau Gumboro menyerang sel-sel dalam organ bursa fabrisius sehingga menyebabkan gangguan terhadap sistem pertahanan tubuh ayam atau bersifat immunosupresif. IBD menjadi salah satu penyakit virus pada ayam yang sering menyerang ayam di lapangan. Penegakan diagnosis IBD dengan tepat, murah, mudah, dan cepat di lapangan sangat penting untuk mengoptimalkan program perawatan dan evaluasi manajemen kesehatan. Tujuan penelitian ini adalah untuk mengetahui penegakan diagnosis IBD dengan melihat gejala klinis dan nekropsi masih bisa diandalkan di lapangan. Metode yang dilakukan adalah dengan melakukan pengamatan gejala klinis pada ayam broiler di peternakan broiler komersial yang diduga terjangkit IBD dan melakukan pengamatan organ pasca mati (nekropsi) terhadap 5 sampel ayam broiler dari peternakan tersebut kemudian dianalisa secara deskriptif. Hasil dari penelitian ini adalah ayam yang terjangkit IBD dapat didiagnosis melalui gejala klinis dan perubahan organ pasca mati, sehingga penegakan diagnosis untuk kasus IBD di lapang dengan pengamatan gejala klinis dan nekropsi masih relevan untuk dilakukan.
\end{abstract}

Kata kunci: Broiler, Diagnosis, Gumboro, IBD, Nekropsi

\begin{abstract}
Infectious Bursal Disease (IBD), also called Gumboro, was disease which attacked cells in the bursa of fabricius, causing interference with the chicken's immune system or immunosuppressive. IBD was the one of viral disease that often attacks chickens in the field. The aim of this study was to determine the diagnosis of IBD by through at clinical symptoms and necropsy that can still be relevant on in the field. The diagnosis of IBD correctly, cheaply, easily and quickly in the field is very important to optimize the health care management and evaluation program. The method used was by observing clinical symptoms of broiler chickens in commercial farms suspected of contracting IBD and observing post-death organs (necropsy). The object of necropsy was 5 samples of broiler chickens from the farm. Data was analyzed descriptively. The results of this study was the broiler chickens that infected with IBD could be diagnosed through clinical symptoms and postdeath organ changes, so that the diagnosis for IBD cases in the field used the observation of clinical symptoms and necropsy are still relevant.
\end{abstract}

Keywords: Broiler, Diagnose, Gumboro, IBD, Necropsy

\section{PENDAHULUAN}

Infectious Bursal Disease (IBD) atau Gumboro merupakan salah satu penyakit yang disebabkan oleh virus dan bersifat akut. Penyakit ini menyerang ayam muda yang berumur kurang dari 4 bulan. Organ yang menjadi target penyakit IBD adalah bursa 
fabrisius dan berbagai organ limfoid sehingga menyebabkan gangguan pada sistem pertahanan tubuh ayam atau bersifat immunosupresif. Kasus IBD memberikan pengaruh yang penting pada peternakan ayam karena infeksi virus tersebut menyebabkan angka morbiditas yang tinggi yaitu 10 sampai 90\% dan memiliki angka mortalitas mencapai $20 \%$, dampak lain dari infeksi IBD adalah menimbulkan gangguan pertumbuhan (Tabbu, 2000). Pada kasus infeksi buatan pada ayam specific pathogen free umur 4 dan 6 minggu angka mortalitas bahkan dapat mencapai $100 \%$ dengan infeksi menggunakan vvIBD strain rB (Stoute et al., 2013). Infectious Bursal Disease (IBD) merupakan penyakit virus menular akut pada ayam yang ditandai dengan peradangan hebat pada bursa fabrisius dan bersifat immunosupresif atau lumpuhnya sistem pertahanan tubuh pada ayam sehingga mengakibatkan turunnya respons ayam terhadap vaksinasi dan ayam menjadi lebih peka terhadap patogen lainnya (Syibli et al., 2008).

IBD masih menjadi bagian dari 5 besar penyakit ayam yang sering menyerang ayam di peternakan Indonesia. Menurut Wiedosari dan Wahyuwardani (2015) menyampaikan bahwa penyakit ayam di Kabupaten Sukabumi dan Bogor teridentifikasi adalah Colibacillosis $(22,2 \%)$, Asites $(12,5 \%)$, Gumboro atau IBD $(12,5 \%)$, Newcastle disease atau ND (10\%), Salmonellosis (10\%), dan Necrotic enteritis $(7,5 \%)$.

Infeksi virus IBD diawali dengan masuknya virus tersebut melalui peroral yang kemudian akan bereplikasi di dalam sel limfosit serta makrofag dalam jaringan usus. Selanjutnya virus IBD akan memasuki sistem sirkulasi peredaran darah dan menyebar ke berbagai organ tubuh hospes termasuk ke bursa fabrisius sebagai target tempat untuk replikasi virus IBD (Van den Berg, 2000). Faktor virulensi virus IBD diperankan oleh salah satu protein dari bagian virus IBD yaitu protein VP-2 juga berperan dalam variasi antigenik dan berperan dalam kemampuan adaptasi virus pada pertumbuhan kultur jaringan (Mahgoub, 2012).

Gejala klinis yang bisa diamati pada infeksi IBD antara lain ayam terlihat lemah atau lesu, bulu kusam, sayap terkulai, dan kadang-kadang dijumpai feses berwarna putih yang menempel pada kloaka (Jackwood et al., 2011). Pada saat dilakukan nekropsi (bedah bangkai) ditemukan perubahan berupa perdarahan pada bagian otot dada dan otot paha (Acribasi et al., 2010). Perubahan pada organ ayam pasca mati yang lainnya ditunjukkan dengan adanya pembengkakan pada bursa fabrisius berupa, lumen bursa fabrisius berisi cairan berwarna kekuningan seperti gelatin, dan perdarahan petechial serta ecchymotic pada permukaan mucosa dan serosa bursa fabrisius (Jackwood et al., 2011).

Pada saat ini penelitian tentang virus IBD sudah banyak dilakukan yang tentunya dapat memberikan banyak manfaat yang diambil untuk mendukung pemberantasan penyakit IBD. Namun, kebutuhan pelaku peternakan untuk bisa mendeteksi kejadian IBD di lapangan juga tidak kalah penting. Penelitian ini bertujuan untuk mengetahui apakah masih ada relevansi penegakan diagnosis IBD di lapangan dengan menggunakan data dari gejala klinis yang diamati dengan didukung pengamatan perubahan organ pasca mati (nekropsi) masih dapat digunakan untuk menegakkan diagnosis IBD di lapangan.

\section{MATERI DAN METODE}

Penelitian ini dilakukan di salah satu peternakan ayam broiler komersil di Bandung yang diduga terinfeksi IBD.

\section{Materi Penelitian}

Materi penelitian yaitu ayam broiler umur 3,5 minggu dengan populasi awal sebanyak 48.000 ekor. Peralatan yang digunakan meliputi spuit $10 \mathrm{~mL}, 1$ set bedah minor, gloves, dan masker. 


\section{Metode Penelitian}

Penelitian ini terdiri dari 2 kegiatan yaitu anamnesa dan pengamatan gejala klinis, serta pengamatan organ pasca mati (nekropsi) kemudian data-data yang dihasilkan dianalisis secara deskriptif.

\section{Pengamatan gejala klinis}

Kegiatan dalam pengamatan gejala klinis ini meliputi anamnesa dengan mengumpulkan data sekunder seperti angka mortalitas dan pengamatan langsung terhadap objek penelitian yang meliputi perubahan-perubahan klinis yang terjadi pada objek.

\section{Pengamatan organ pasca mati}

Kegiatan pengamatan organ pasca mati yaitu mengamati dan mencatat perubahan yang terjadi pada organ-organ objek terutama pada bursa fabrisius, airsaccus, dan jantung. Objek yang dilakukan nekropsi sebanyak 5 ekor ayam yang dipilih secara acak (kondisi sakit parah). Sebelum dilakukan nekropsi, ayam diamati dan dicatat terlebih dahulu semua perubahan yang ada di bagian luar tubuh kemudian dilakukan euthanasia dengan cara emboli. Setelah itu, dilakukan nekropsi dan diamati semua perubahan yang terjadi pada organ-organ target.

\section{Analisis data}

Hasil dari pengamatan gejala klinis dan pengamatan perubahan organ pasca mati kemudian dibandingkan dengan literatur dan dianalisis secara deskriptif.

\section{HASIL DAN PEMBAHASAN}

Penelitian yang terkait dengan relevansi metode penegakan diagnosis IBD di lapangan berdasarkan data dari hasil pengamatan gejala klinis dan perubahan organ pasca mati masih relevan untuk penegakan diagnosis pada kasus IBD. Hal ini didukung dengan banyaknya perubahan ataupun mutasi penyakit terutama yang disebabkan oleh virus di lapangan. Identifikasi Inclusion Body
Hepatitis (IBH) di lapangan pada awalnya tidak mudah untuk dibedakan dengan diagnosis IBD.

Pengamatan gejala klinis pada umur 21 sampai dengan 25 hari didapatkan hasil yang menunjukkan beberapa perubahan klinis seperti ayam secara umum terlihat lesu, bulu kusam, nafsu makan menurun, diare encer dengan dominasi warna putih dengan kloaka yang kotor, dan posisi sayap banyak yang terkulai (Gambar 1.). Angka mortalitas pada ayam penelitian mengalami peningkatan yang signifikan terutama pada umur 21 hari sampai 25 hari yaitu dari angka 0,75\% meningkat menjadi 1,38\%.

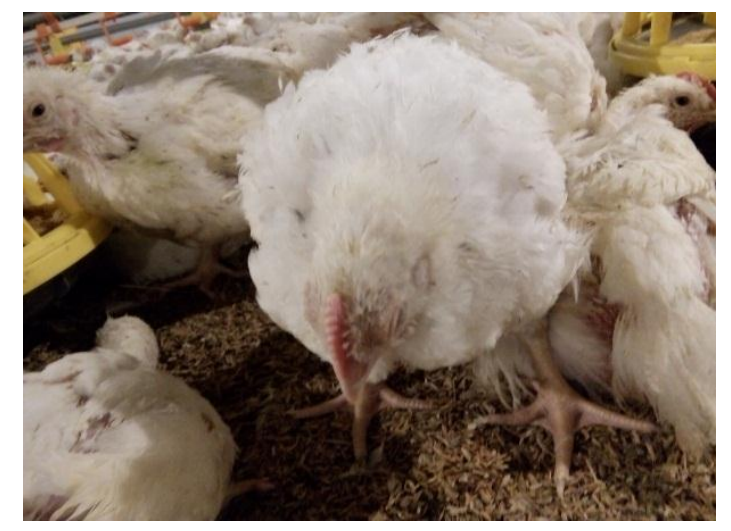

Gambar 1. Kondisi klinis ayam broiler

Menurut Jackwood et al. (2011) gejala klinis yang bisa diamati pada infeksi IBD meliputi ayam terlihat lemah atau lesu, bulu kusam, sayap terkulai, dan kadang-kadang dijumpai feses berwarna putih yang menempel pada kloaka. Tabbu (2000) menjelaskan bahwa pada kasus IBD diawali dengan gejala sejumlah ayam mematuk daerah kloaka dan sekitarnya yang kemudian diikuti dengan diare encer berwarna putih, daerah kloaka kotor, bulu berdiri, tremor, kelemahan, dan berakhir dengan kematian.

Hasil dari pengamatan gejala klinis yang dibandingkan dengan literatur terkait gejala klinis ayam teridentifikasi IBD menunjukkan bahwa ayam dari objek penelitian diduga terinfeksi IBD dan secara umum gejala klinis IBD masih belum ada perkembangan perubahan klinis yang lain di lapangan. 
Namun, dari gejala klinis pada ayam objek penelitian masih menunjukkan kemiripan dengan kasus lain seperti IBH. IBH memiliki gejala klinis yang meliputi anemia, sayap terkulai, jengger dan pial pucat, kematian mendadak, angka mortalitas mencapai $10 \%$, dan menyerang ayam muda yang berumur 4 sampai 8 minggu (Direktorat Kesehatan Hewan, 2014). Padhy et al. (2015) pada kasus IBH akan dijumpai gejala klinis yang antara lain, yaitu: kelesuan, bulu acak-acakan dan berhamburan, serta kotoran yang berwarna kekuningan.

Nekropsi dilakukan untuk melihat perubahan organ yang terjadi pada objek. Hal ini akan memperkuat data dalam menegakkan diagnosis suatu penyakit dari ayam. Nekropsi merupakan suatu metode yang cepat, murah, mudah, dan tepat untuk melihat perubahan organ-organ pasca mati di lapangan yang memberikan gambaran lebih mendalam dari pathogenesis suatu penyakit.

Tabel 1. Perubahan Organ Pasca Mati

\begin{tabular}{ll}
\hline \multicolumn{1}{c}{ Objek } & \multicolumn{1}{c}{ Perubahan Pasca Mati } \\
\hline Ayam 1 & $\begin{array}{l}\text { Bengkak dan hemoragi pada bursa fabrisius, airsacculitis, hemoragi pada } \\
\text { jantung }\end{array}$ \\
\hline Ayam 2 & $\begin{array}{l}\text { Bengkak dan hemoragi serta cairan kekuningan pada bursa fabrisius, } \\
\text { airsacculitis, hemoragi pada jantung }\end{array}$ \\
\hline Ayam 3 & $\begin{array}{l}\text { Bengkak dan hemoragi pada bursa fabrisius, airsacculitis, hemoragi pada } \\
\text { jantung }\end{array}$ \\
\hline Ayam 4 & $\begin{array}{l}\text { Bengkak dan hemoragi serta cairan kekuningan pada bursa fabrisius, } \\
\text { airsacculitis, hemoragi pada jantung }\end{array}$ \\
\hline Ayam 5 & $\begin{array}{l}\text { Bengkak dan hemoragi serta cairan kekuningan pada bursa fabrisius, } \\
\text { airsacculitis, hemoragi pada jantung }\end{array}$ \\
\hline
\end{tabular}

Hasil dari pengamatan organ-organ pasca mati pada ayam objek penelitian adalah terjadinya perubahan pada bursa fabrisius yaitu dijumpai hemoragi dan masa berlendir berwarna kekuningan, terjadinya peradangan pada airsaccus (airsacculitis), serta dijumpai hemoragi di jantung (Tabel 1).

Bursa fabrisius pada kasus IBD merupakan organ target virus IBD untuk melakukan replikasi sehingga dipastikan terjadi perubahan pada organ bursa fabrisius berupa kerusakan, perdarahan (hemoragi), dan pembengkakan (Jackwood et al., 2011). Pada ayam objek penelitian semua bursa fabrisius mengalami pembengkakan dan hemoragi yang ditunjukkan pada Gambar 2 . Pada ayam objek penelitian 2, 4, dan 5 juga dijumpai cairan kekuningan. Hal tersebut menggambarkan bahwa adanya kerusakan pada organ tersebut. Syibli et al. (2008) juga menjelaskan bahwa pada kasus IBD maka akan dijumpai peradangan yang hebat pada bursa fabrisius.



Gambar 2. Pembengkakan, hemoragi, dan cairan kekuningan pada bursa fabrisius (panah)

Airsaccus semua ayam objek penelitian dijumpai adanya peradangan (airsacculitis) yang digambarkan dengan adanya masa berkabut sampai buih berwarna keputihan pada airsaccus. Kasus IBD menurut Elanco Animal Health (2010) airsacculitis dengan 
derajat sedang sampai berat bisa dijumpai pada kasus IBD karena adanya kemungkinan infeksi sekunder pada saluran pernafasan yang muncul akibat turunnya sistem pertahanan tubuh karena bursa fabrisius yang mengalami kerusakan.

Hemoragi pada jantung objek penelitian sangat dimungkinkan merupakan akibat dari infeksi sekunder. Tabbu (2000) menerangkan bahwa ayam yang terserang IBD paling sering diikuti oleh infeksi sekunder penyakit ND, CRD, dan Collibacillosis.

Organ hati ayam objek penelitian juga diamati untuk dapat membedakan dengan kasus IBH dan pada penelitian lapang ini tidak ditemukan adanya perubahan pada organ hati atau organ hati ayam objek penelitian dalam kondisi normal (Gambar 3). Kasus IBH dijumpai dengan adanya necrosis focal dan badan intranuklear inclusion body pada organ hati (Padhy et al., 2015).

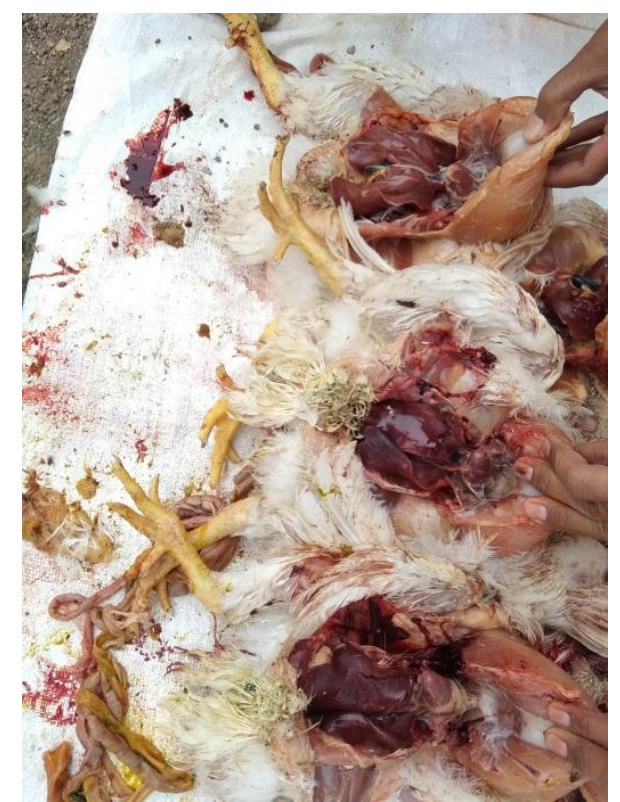

Gambar 3. Organ hati ayam objek penelitian

Hasil pengamatan organ-organ pasca mati dan gejala klinis dari ayam objek penelitian maka menunjukkan bahwa ayam objek penelitian didiagnosis positif IBD. Pengamatan gejala klinis yang diperkuat dengan perubahan organ-organ pasca mati masih relevan untuk digunakan sebagai metode cepat dalam penegakan diagnosis IBD di lapangan.

\section{KESIMPULAN}

Penegakan diagnosis pada kasus IBD dengan pengamatan gejala klinis dan didukung dengan pengamatan organ-organ pasca mati masih relevan untuk digunakan sebagai metode yang cepat, murah, tepat, dan mudah dilakukan di lapangan.

\section{DAFTAR PUSTAKA}

Acribasi, M., A. Jung, E.D. Heller, S.S. Rautenschlein, and T.P. Van den Berg. 2010. Differences in genetic background influence the induction of innate and acquired immuneresponses in chickens depending on the virulence of the infecting infectious bursal disease virus (IBDv) strain. Veterinary Immunology and Immunopathology. 135:79-92.

Direktorat Kesehatan Hewan. 2014. Manual Penyakit Unggas. Direktorat Jenderal Peternakan dan Kesehatan Hewan. Kementerian Pertanian. Jakarta.

Elanco Animal Health. 2010. Productivity: Information + Knowledge $=$ Competitive Advantage. https://www.elanco.co.uk /products-services/poultry/

productivity. Diakses tanggal 21 Februari 2019.

Jackwood, D.J., S.E. Sommer-Wagner, B.M. Crossley, S.T. Stoute, P.R. Woolcock, and B.R. Charlton. 2011. Identification and pathogenicity of a natural reassortant between a very virulen serotype 1 infectious bursal disease virus (IBDV) and a serotype 2 IBDV. Virology. 420:98-105.

Mahgoub, H.A. An overview of infection bursal disease. Archives of Virology. 157:20472057.

Padhy, Arpita, Sahu, Amit Ranjan, Sahoo, Saraswat, and S. Ganguly. 2015. Chicken infectious anemia: A Review on its 
potential threat to poultry industry worldwide. World Journal of Biology and Medical Science. 2(4):17-19.

Stoute, S.T., D.J. Jackwood, S.E. SommerWagner, B.M. Crossley, P.R. Woolcock, and B.R. Charlton. 2013. Pathogenicity associated with coinfection with very virulent infectious bursal disease and Infectious bursal disease virus strains endemic in the United States. Journal of Veterinary Diagnostic Investigation. 20(10):1-7.

Syibli, M., S. Nurtanto, N. Lubis, Syafrison, S.N.D.K. Yulianti, C.K. Yohana, E. Setianingsih, Nurhidayah, D. Efendi, dan E. Saudah. 2008. Manual Penyakit Unggas. Direktorat Jenderal Peternakan dan Kesehatan Hewan. Kementerian Pertanian. Jakarta.

Tabbu, C.R. 2000. Penyakit Ayam dan Penanggulangannya Vol 1. Kanisius. Yogyakarta.

Van den T.P. Berg. 2000. Acute infectious bursal disease in poultry: a review. Avian Pathology. 29(30):175-194.

Wiedosari, E. dan S. Wahyuwardani. 2015. Studi kasus penyakit ayam pedaging di Kabupaten Sukabumi dan Bogor. Jurnal Kedokteran Hewan. 9(1):9-13. 